\title{
A Pragmatic Analysis of Deixis in a Religious Text
}

\author{
T. A. Suhair Adil Abdulameer ${ }^{1}$ \\ ${ }^{1}$ College of Education for Women, Al Iraqia University, Baghdad, Iraq \\ Correspondence: T. A. Suhair Adil Abdulameer, College of Education for Women, Al Iraqia University, Baghdad, \\ Iraq. E-mail: suheradel75@gmail.com
}

Received: December 14, 2018 Accepted: January 9, 2019 Online Published: March 2, 2019

doi:10.5539/ijel.v9n2p292 URL: https://doi.org/10.5539/ijel.v9n2p292

\begin{abstract}
This research tackles the pragmatic analysis of deixis in a religious text. It aims at: 1) Identifying and showing the occurrences of deixis in the religious text. 2) Finding out the most dominant type of deixis in the text. 3) Analyzing the reasons behind using these types of deixis and how they affect the audience who hear or read the speech. The source of data was taken from a religious lecture presented by Imam John Starling at Queens College in 22/10/2014 about imaan (faith) which is taken as a sample. The procedure followed in this research was reading and writing down the deictic expressions: person, place and time deixis. The findings showed that person deixis occurred for 202 times, place deixis for 11 times and time deixis for 6 times only, which indicates that the most dominant type is person deixis. After analyzing the three types of deixis in this text, the researcher has concluded that the reason behind the frequent use of person deixis could be due to the particularity of the religious texts which are centered on the Divine Entity, thus the speakers/writers always making a reference to God by using the third person pronoun ' $\mathbf{H e}$ '. In addition, this kind of texts is usually about guidance and advice, therefore, the pronoun 'You' also occurs frequently to address the audience directly and to draw their attention. And since the adviser (imam) wants to make his audience feel that he belongs to them and shares with them the same destiny, he used the pronouns ' $\boldsymbol{W}$ ' and ' $\boldsymbol{U} \boldsymbol{s}$ '. In return, place and time deixis are very few in this text and occurred mostly during narrating some stories and setting some examples.
\end{abstract}

Keywords: John Starling, religious text, personal deixis, place deixis, time deixis

\section{Introduction}

\subsection{The Basis of the Study}

Pragmatics is a subfield of linguistics that deals with language in use and how the context contributes to meaning. It includes such matters as deixis, conversational implicature, text organization, speech act theory and presupposition.

It doesn't depend only on the linguistic meaning, but also on the context, real-world knowledge and inference in dissolving types of linguistic ambiguities including deixis.

Deixis, on the other hand, is a term which refers to words and phrases that cannot be understand without the contextual information. Thus, it is a crucial subject in the field of pragmatics.

According to Fillmore and Lyons, there are three main types of deixis: person deixis, place deixis and time deixis. Later, two types of deixis have been added by Levinson: discourse deixis and social deixis.

Person deixis refers to grammatical categories of people involved in an utterance and expressed by persons: first person deixis (I, we), second person deixis (you) and third person deixis (he, she, it and they).

Place deixis refers to words and phrases used to point to a location which is relevant to the location of a participant in the speech event. It has three forms: adverbs of place, such as 'here' and 'there', demonstratives that refer to a person or thing 'this', 'that', 'these' and 'those', and motion verbs, particularly 'come' and 'go'.

Time deixis refers to a temporal reference which points to the moment of speaking. Time deixis is represented by adverbs of time, such as 'yesterday', 'now', 'then', 'tomorrow' ...etc., and the verb tenses.

In all types of text, including religious texts, we can find deictic expressions that need a pragmatic analysis to be interpreted, since pragmatics provides the contextual information that is necessary to understand the hidden meaning. 


\subsection{Aims of the Study}

The research aims at:

1) Identifying and classifying selected occurrences of deixis which are used in a religious text.

2) Finding out the most dominant type of deixis in the text.

3) Analyzing the reasons behind using these types of deixis and how the hearers/readers are affected by them.

\subsection{The Procedure of the Study}

This research is divided into two parts, the first is the theoretical background, and the second is the practical; the analysis of the text.

The researcher has randomly downloaded a religious lecture given by Imam John Starling at Queens College in 22/10/2014 about imaan (faith).

The technique used in this research is reading and writing down the deictic expressions; person, place and time deixis, trying to show their frequent occurrences in the text and giving acceptable interpretation for their use.

\subsection{Limits of the Study}

The limits of the study are:

1) Analyzing one type of texts, a religious text.

2) The religious text which is going to be analyzed is a lecture by Imam John Starling at Queens College in 22/10/2014 about imaan.

3) Three types of deixis are going to be analyzed: person, place and time deixis.

\subsection{Significance of the Study}

1) The research presents a detailed survey of the concept of pragmatics and deixis which is hoped to enrich students' and researchers' knowledge about them.

2) It's thought that this research can help students and researchers of language to understand deictic expressions in other types of religious texts such as Qur'an, Hadith, Juma' prayer speeches and the like.

3) It's also hoped that this research could help students and researchers of language to understand deictic expressions in different types of text, such as literary, political, legal, ...etc.

\section{Literature Review}

\subsection{Pragmatics}

Most definitions of pragmatics have been inspired by Charles Morris's definition of pragmatics as "the study of the relations of signs to interpreters" (1938) (Mey, 1996, p. 35).

Morris added that "pragmatics is about everything human communication process, psychological, biological and sociological".

In Levinson's words, "pragmatics is the study of those relations between language and context that are grammaticalized, or encoded in the structure of a language" (Ibid, p. 39).

It is the systematic study of meaning depending on the use of language. The main topics of pragmatics are: implicature, presupposition, speech acts and deixis (Huang, 2007, p. 3).

Pragmatic factors such as context, real-world knowledge and inference are essential to fill the gap created by linguistic underdetermining. It's for this reason, pragmatics has to be included as a component in an overall theory of linguistic ability (Ibid, p. 6).

In this sense, Yule (2010, p. 128) stated that pragmatics studies the hidden meaning, or how we recognize what is meant even if it isn't actually said or written. Therefore, the speakers (or writers) must be able to depend on a lot of shared presuppositions and expectations when they communicate.

In order to understand the messages that are intended to be conveyed, we must use the meanings of the words, the context in which they occur and some pre-existing knowledge of what is intended to be conveyed. Our interpretation of the meaning of the sign is not only based on the words, but on what we think the writer intended to communicate (Ibid, p. 129).

Pragmatics assumes that when people communicate with each other they follow some sort of co-operative principle; that is, they have a shared understanding of how they should co-operate in their communications. The 
sentence "The bus was late" could have different interpretations, it could mean a complaint by some person against the bus service, or an explanation by other people about why they're late, or anything else. So, to determine what the previous sentence could have meant, pragmatics is needed as it provides the social and textual context and the background knowledge context, i.e., what people know about each other and about the world. This helps to know what people typically say and do as they perform particular genres in particular social and cultural settings (Paltridge, 2008, p. 53).

Yule (1996, p. 3) gave four definitions for pragmatics according to the four areas that is concerned with. First: it is the study of speaker meaning, that is, it is concerned with the study of meaning as communicated by a speaker (or writer) and interpreted by a listener (or reader). As a result, it has more to do with the analyzing of what people mean by their utterances than what the words or phrases in those utterances might mean by themselves.

Second: it studies the contextual meaning, i.e., it is concerned with the interpretation of what people mean in a particular context and how the context influences what is said. It takes into consideration how speakers organize what they want to say in accordance with who they're talking to, where, when and under which circumstances.

Third: pragmatics studies how more gets communicated than is said. This approach investigates how listeners can make inferences about what is said in order to arrive at an interpretation of the speaker's intended meaning. It explores how a great deal of what is unsaid is recognized as part of what is communicated, i.e., it is the investigation of invisible meaning.

Fourth: It studies the expression of relative distance. In this respect, pragmatics determines the choice between the said and the unsaid. Closeness, whether being physical, social or conceptual, implies shared experience. Speakers determine how much needs to be said according to how close or distant the listener is.

Lyons (1981) (cited in Al-Tekreeti, 2016, p. 6) defined pragmatics as "the study of actual utterances; the study of use rather than meaning; the study of that part of meaning which is not purely truth-conditional; the study of performance rather than competence." Lyons here concentrated on the user and the context of language use rather than on meaning, grammar or truth.

Also Crystal (2008) (cited in Ibid) stated that pragmatics is the study of communicative actions in its socio-cultural context. Thus, he defined pragmatics as "the study of the principles governing the communicative use of language, especially as encountered in conversations-principles which may be studied as putative universals, or restricted to the study of specific languages."

To sum up, pragmatics is the study of language used for the purposes of communication and the study of what the speakers mean when they produce utterances, by depending on the context rather than on the literal meaning of the words.

Verbal interactions can be expressed in indirect ways which may lead to misunderstanding for the hearer.

These interpretations vary, since people sometimes do not understand the invisible meaning of messages in everyday communication. Hence, pragmatics deals with the implied messages and how people understand the meaning even if it is not said or written (Ibid, pp. 7-8).

\subsection{Context}

Context, as has been illustrated, is very essential to solve any ambiguity or misunderstanding and make the meaning clearer.

The term 'context' is used in linguistics and phonetics to refer to certain parts of utterance, or text near a unit which is the focus of attention. The occurrence of a unit, such as a sound or word is determined by its context, which is specified in terms of the unit's relation, that is, the other features with which it combines as a sequence (Crystal, 1985, p. 71).

Chastain (1975, pp. 239-240) defined context as "something which has content, which could represent something or situation, and which could contain singular terms or analogous elements which could be referentially connected with objects in the world."

Context helps to determine meaning; nearly all words and most sentences are ambiguous when they're out of context. In all ordinary speech, the basis for understanding each single word is not that word alone, but also the context which includes accompaniment circumstances, situation, knowledge of the topic of the speaker's habits and opinions ....etc.

Consequently, for the hearer/reader to understand an utterance or a sentence, he must bring to bear certain items of background information not specifically mentioned in the utterance or sentence. It's the context which guides 
the hearer/reader to the correct actualization of a particular element of meaning which is intended by the speaker/writer (Stern, 1968, pp. 304-305; Sperber \& Wilson, 1982, pp. 61-62).

H. G. Widdowson, who focused his study on language meaning, defined context as "those aspects of the circumstance of actual language use which are taken as relevant to meaning". He added "context is a schematic construct ... the achievement of pragmatic meaning is a matter of matching up the linguistic elements of the code with the schematic elements of the context."

Guy Cook defined context as just a form of knowledge the world, and it can be used in a narrow and a broad sense. In a narrow sense it refers to 'knowledge of' factors outside the text under consideration. In the broad sense, it refers to 'knowledge of' these factors and to (knowledge of) other parts of the text under consideration, which is also called 'co-text'.

As for reference and inference, George Yule defined context as "the physical environment in which a word is used".

All these definitions have an important point in common: context is the environment in which a discourse occurs (Song, 2010).

Context is of two types: linguistic context, also called co-text, and context of situation. Linguistic context refers to the syntax which governs the construction of sentences. It consists of parts which immediately precede or follow a passage or text and identify its meaning. This type of context can account for syntactic ambiguity (Palmer, 1976, pp. 43-44; Brand Ford et al., 1980, p. 17).

Context of situation, on the other hand, is related to semantic and pragmatic ambiguities, that is, ambiguities arising from lexical items and knowledge of the real world (Palmer, 1976, pp. 43-44).

For Firth, language should not be studied as an isolated mental system, but as a response to the context of particular situations (Getty \& Tolkien, 2018).

Meaning, according to Firthian linguistic theory, is looked at as a multiple phenomenon; its various aspects are related on one hand to external life features, and on the other hand to the different levels of linguistic analysis, like phonetics, grammar and semantics. It refers to the whole set of external world features that are relevant in the analysis of an utterance of these levels (Crystal, 1985, p. 72).

Context of situation is part of what's called 'cultural context' which is defined as the context that describes the environment for the whole set of linguistic options available, the sum of all that is feasible and formally correct. It refers to a specific culture with its social institutions and interests, beliefs and doctrines, customs and traditions, moral and aesthetic values ... etc.

The concept of cultural context has been widened by Bronislaw Malinowski, the Polish anthropologist, to include not only spoken words but also facial expression, gestures, bodily activities, as well as the whole group of people present during an exchange of utterances and the part of environment on which these people are engaged (Edwards, 1976, p. 35; Halliday, 1978, p. 109).

Moreover, cultural context is part of what is called 'social context' which is defined by Halliday as the semantic environment in which people exchange meaning, that is, the meaning of a word or sentence is understood by participants on the basis of social factors (Casson, 1981, p. 17).

\subsection{Deixis}

Deixis is a technical term derived from the Greek word meaning 'pointing' via language. It is concerned directly with the relationship between the structure of a language and the context in which the language is used. It is the phenomenon whereby features of context of utterance or speech event are encoded by lexical or grammatical means in a language.

Deictic expressions are also sometimes called 'indexicals' which include (1) demonstratives, (2) first- and second-person pronouns, (3) tense markers, (4) adverbs of time and place and (5) motion verbs (Yule, 1996, p. 9; Huang, 2007, p. 132).

Deixis is an important part of pragmatics that cannot be ignored in terms of language use, because its interpretation depends on the context and the speaker intention.

There are some common words that can't be interpreted at all without their context, particularly the context of situation [such words 'here' and 'there', 'this' or 'that', 'now' and 'then', 'yesterday', 'today' or 'tomorrow', as well as pronouns such as 'you', 'me', 'she', 'him', 'it' and 'them' are impossible to understand if we don't know who is speaking, about 'whom', 'where' and 'when'. 
A sentence like "You'll have to bring it back tomorrow because she isn't here today", is really vague because it contains a large number of expressions (you, it, tomorrow, she, here, today) that depend on knowledge of the immediate context for their interpretation, i.e., that the delivery driver will have to come back on February 15 to 660 College Drive with the long box labled "Flowers, handle with care" addressed to Lisa Landry (Yule, 2010, p. 130).

There are two uses of deictic expressions: 'deictic' use and 'non-deictic' use. Within deictic use, further distinction can be drawn between 'gestural' and 'symbolic' use. Gestural use can only be interpreted by a direct, moment by moment monitoring of some physical aspects of the speech event. For example, in "you and you but not you, go back to your dorms!" the deictic expressions can be interpreted only if they're accompanied by a physical demonstration, like a selecting gesture or eye contact of some sort.

The interpretation of the symbolic use of deictic expressions, on the other hand, involves knowing the basic spatio-temporal parameter of the speech event. If we hear someone uttering "This town is famous for its small antique shops", we do not expect the utterance to be accompanied by any physical indication of the referent.

In addition, we know the general location of the speaker, we can understand it without any problem (Huang, 2007, p. 134).

The 'non-deictic use' is an expression for which we don't need context to understand, because it is not referring to a specific thing. For example, "I do 'this' and 'that", the 'this' and 'that' do not refer to anything specific (Al-Tekreeti, 2016, p. 12).

\subsubsection{Types of Deixis}

Linguists as Lyons and Fillmore classified deixis into three major types: person deixis, place deixis and time deixis. Later on, Levinson added two more types of deixis: discourse and social deixis (Ibid, p. 13).

\subsubsection{Person Deixis}

Person deixis is a deictic reference to the participant role of a referent. It deals with the grammatical categories of people involved in an utterance. It includes: the speaker, the addressee and referents which are neither speaker nor addressee.

Person deixis is commonly expressed by: pronouns, possessive affixes of nouns and agreement affixes of verbs.

It is of three kinds: (1) first person deixis (I, we) which refers to the speaker or to group of speakers. (2) Second person deixis (you) which refers to the addressee or a group of addressees, and (3) third person deixis (he, she, it and they) refers to other participants in the context of situation, neither speaker or addressee.

All of them depend on the participant's role in the utterance directed and on the addressee, and can come in plural and singular form (Lyons, 1979) (Cited in Al-Tekreeti, 2016, p. 13; Glossary Terms, 2018).

\subsubsection{Place (Spatial) Deixis}

Words and phrases used to point to a location, such as, 'here', 'there', 'near that' are called spatial deixis (Yule, 2010, p. 130).

Place deixis is an expression used to show the location which is relevant to the location of a participant in the speech event.

The relative location of people and things is being indicated. It's usually expressed in 'this', 'those', 'there', 'here', 'that' and 'those'.

Cummings (2005) stated that those references to place can be absolute or relational in nature. Absolute references to place locate an object or person in a specific longitude and latitude, whereas relational references locate people and place relational references locate people and place in terms of each other and the speaker (Wijaya, 2012).

Place deixis has three forms: (1) adverbs of place such as 'here' and 'there', (2) demonstratives which refer to a person or thing, they're: 'this', 'that', 'these' and 'those', (3) the motion verbs which are another form of deixis, especially 'come' and 'go'. These verbs are deictic when they are used to indicate movement towards or away from the speaker. So, if a person, for example moves towards us we say 'he comes', but if he moves away from us we say 'he goes'.

Place deixis can also be used to indicate a psychological proximity between the speaker and the referent; it is called, according to Levinson (1983), 'empathetic deixis'. In the sentence "I don't like that", the speaker expresses his attitude towards someone's bad behavior that makes him nervous. 
Levinson (1983) stated that distance is a concept which is linked with place deixis and has two dimensions in the deictic system: proximal, near or close to speaker and distal dimension, remote from the speaker and/or closer to addressee. To refer to the proximal or near entity, 'this', 'these' and 'here' are used, whereas 'that', 'those' and 'there' refer to the distal entity.

Lyons (1977) illustrated that the distinction between 'this' and 'that' and 'here' and 'there' depends on the proximity to the zero-point of the deictic context which is specified by the location of the speaker at the time of speaking. "This boy", for example, is understood as the boy "who is here' near the speaker, whereas "that boy" is understood as the boy who is 'there' far from the speaker (Al-Tekreeti, 2016, p. 18).

\subsubsection{Time (Temporal Deixis)}

Time deixis "is concerned with the ending of temporal points and spans relative to the time at which an utterance is produced in a speech event" (Huang, 2007, p. 144).

It refers to the expressions that deal with the time of speaking. Renkema (1993) stated that time deixis is a reference to time relative to a temporal reference point and it is typically the moment of speaking. Time expressions are represented by adjectives of time, such as 'yesterday', 'now', 'tomorrow' and the verb tenses.

In addition Levinson (1993) stated that the basis for systems of reckoning and measuring time in most languages are the natural and prominent cycles of day and night, months, seasons and years. Another time deixis is stated by Grundy (2000) that is "tense system". He declared that almost every sentence makes reference to an event time which can only be determined in relation to the time of the utterance (Wijaya, 2012).

Likewise, Yule (1996, pp. 14-15) said that in English the basic type of temporal deixis is the choice of verb tense. English has only two basic forms: the present and the past. For example, the present tense in "I live here now" is the proximal form, whereas the past tense is distal form in "I live there then".

Deictic forms of temporal deixis are usually expressed by adverbs of time, such as 'today', 'yesterday', 'now', 'then', ...etc., which are single words that reflect the time of the utterance, and complex time adverbials which consist of a deictic modifier plus non-deictic measure word, such as 'last month', 'next year', 'this afternoon', 'last Monday', ...etc. This way of referring is called calendrical reckoning (Levinson, 1983; Al-Tekreeti, 2012, p. 16).

A distinction can be made between 'calendrical' and 'non-calendrical' time units. Calendrical usage refers to a fixed length sequence of a naturally given time unit, such as: 'July', 'Sunday', 'this morning', whereas non-calendrical usage refers to the periods of measurement in relation to some fixed points of interest such as, 'now', 'evening', and 'fortnight' (Huang, 2007, p. 144).

The calendrical units are non-deictic, but they can be deictic by adding demonstratives as modifiers to them. For example, 'this morning' means the morning that includes the time of speaking, and 'this June' indicates the 'June' of the calendrical year which includes the time of speaking. Non-calendrical units, on the other hand are deictic (Al-Tekreeti, 2012, p. 17).

\subsubsection{Discourse (Text) Deixis}

Discourse deixis describes deictic expressions which indicate prior or succeeding parts of the discourse. In other word, the words and phrases that indicate the relationship between an utterance and the prior discourse. It's a kind of commentary on the text or conversation by the speaker.

Expressions like: 'but', 'therefore', 'in conclusion', 'actually', 'all in all' ...etc., help to construct the discourse and to range the current utterance in a chronological order (ELLO, 2018).

Discourse deixis is used for words which refer backgrounds (by what is called 'anaphora'), or forwards (another term 'cataphora') (Suleymanova, 2018). For example, the use of the proximal demonstrative 'this' in "This is how birds evolved from predatory dinosaurs" anticipates information to be conveyed in an upcoming stretch of the discourse. The same is true for the use of the proximal adverb of place 'here' in "Here goes the same argument". On the contrary, the use of the distal demonstrative 'that' in "That's tonight's evening news" refers back to a preceding segment of the discourse (Huang, 2007, p. 172).

Levinson (1983) stated that the distinction should be made between discourse deixis and anaphoric expression. Discourse deixis shares with anaphora and cataphora the capacity to function as a text cohesion device. Anaphora is concerned with the use of a pronoun to refer to the same referent as some prior term. It can hold within sentences, across sentences, and across at speaking in a dialogue. Deictic expressions are used to introduce a referent, and anaphoric pronouns are used to refer to the same entity thereafter. When a pronoun refers to a linguistic expression itself, it is discourse deixis, otherwise, if the pronoun refers to the same entity as 
a prior linguistic expression refers to, it is anaphoric (Wijaya, 2012).

\subsubsection{Social Deixis}

Social deixis is "concerned with the codification of the social status of the speaker, the addressee, or a third person or entity referred to, as well as the social relationships holding between them" (Huang, 2007, p. 163). The information carried by social deixis may include social class, kin relationship, age, sex, profession and other group.

Social deixis show how different social rankings and the participants of communication utter relationships within society by using language. It refers to the level of relationship between people than to information (Wijaya, 2012).

For example, a sentence like "Sir, you have a visitor" the word 'sir' refers to the rank of the addressee who is in a high social class than the speaker (Al-Tekreeti, 2016, p. 21).

Social deixis can be expressed by:

1) Title of addressee (Sir, Mr., Miss).

2) Kinship terms (uncle, my uncle).

3) First name (James).

4) Combination (James Bond).

5) Titles borrowed from names of occupations (doctor).

6) Ranks in certain social/ professional groups (Colonel).

7) Combination of titles and names (Professor Sir John Lyons) (Dondeigo, 2018).

There are two main categories of social deixis: 'Relational' social deixis and 'Absolute' social deixis. Relational social deixis can be represented between (1) speaker and referent (referent honorifics), which are forms employed by the speaker to show respect towards the referent, (2) speaker and addressee (addressee honorifics), which are forms used by the speaker to show deference towards the addressee, and (3) speaker and bystander (bystander honorifics) which are forms used by the speaker to signify respect to a bystander, including participant in the role of audience and non-participant overhearers (Huang, 2007, p. 164).

Absolute social deixis, on the other hand, is a deictic reference to some social characteristics of a referent (especially a person) regardless of any relative ranking of referents. It doesn't include comparison of the ranking of the speaker and addressee, there's only a simple reference to the absolute status of the addressee such as 'Your Majesty', 'Your Honor', or 'Mr. President' (Al-Tekreeti, 2016, p. 22; Glossary Terms, 2018).

\section{Data Analysis}

In this research, the researcher aims to figure out the importance of using deixis in formal speech, namely, religious text, to analyze the intention behind using different types of deixis in the speech and to discuss how often these types are used and how they affect the audience who read or hear it.

Accordingly, the researcher has randomly downloaded a religious lecture given by John Starling, an American Imam of a mosque in New Jersey at Queens College in 22/10/2014 about Imaan (faith).

This lecture represents a methodical scholarly lesson based on verses of the Holy Qur'an and the correct Hadith of the Prophet Mohammed, God's blessings and peace be upon him. It contains glimpses of belief, worship, religious rulings, Islamic ethics and high morals in a clear and plain language.

The technique used in this research is reading and writing down the deictic expressions, personal, spatial and temporal, trying to show whether there are deictic expressions used more frequent than the others or not and why.

\subsection{Analysis of the Results and Discussion}

The collected data show that person deixis is the mostly used type in this text followed by place deixis which is less frequent, and finally time deixis which is seldom used during this lecture.

The table below shows the frequency of the use of each type of deixis during the lecture. 
Table 1. Frequency of deixis expressions

\begin{tabular}{|c|c|c|c|c|c|c|c|c|}
\hline \multicolumn{3}{|l|}{ Person Deixis } & \multicolumn{3}{|c|}{ Place Deixis } & \multicolumn{3}{|c|}{ Time Deixis } \\
\hline first person & second person & third person & Proximal & distal & others & proximal & distal & others \\
\hline 35 times & 69 times & 98 times & / & 2 times & 9 times & 1 time & 2 times & 4 times \\
\hline
\end{tabular}

The table clearly shows that the mostly used type of deixis in this text is the person deixis, especially the third person deixis that the Imam mentioned for 98 times during his lecture. The second type of deictic expressions used is the place deixis which is divided into proximal and distal both mentioned for 2 times. Other spatial expressions are mentioned for 9 times. Last is the time (temporal deixis) mentioned for 7 times only by the Imam.

\subsubsection{Reasons Behind the Use of Person Deixis}

As it has been shown previously, person deixis is the most frequent type used in this text. In details, the mostly used is the third person (he) and its possessive and reflexive forms (his).

Since it is a religious text, the words (Allah) or (God) and the pronoun (He), which replaces the name of almighty God, are widely used in such texts. It is written with a capital letter indicating honor and glorification. The following sentences improve this:

1) All praise is due to Allah. We praise 'Him' and seek 'His' help and forgiveness.

2) 'He' whom Allah guides, no one can misguide, and he whom 'He' misguides, no one can guide.

3) Allah has perfected 'His' creation.

4) 'He' set the sun and moon in their courses.

5) 'He' says "so worship me" ...etc.

The third person pronoun refers to absent people (or things) who are not addressed directly by the addressor. This happens when the speaker/writer writes or talks about people or characters of a story who are not present in the place of sermon.

In religious texts, we often find examples of stories of people whose life stories are used to clarify and strengthen the meaning that the speaker/writer wants to convey to the audience. Let's consider the following examples: "The thieves are not believers whilst 'they' are in the act of committing theft-it means 'they' are weak in imaan, but not to the point that 'they' have left the faith" this example demonstrates a general fact taken from Prophet Mohamed's Hadith that a thief has no belief in Allah when committing his crime of theft. The pronoun 'they' refers to the thieves.

The Imam told his audience a story about Al-Fudhayl Ibn Iyaad in which he widely used the third person pronouns ' $\boldsymbol{h} \boldsymbol{e}$ ' and 'they' less frequently, ' $\boldsymbol{h} \boldsymbol{e}$ ' replaces the main character of the story, Al-Fudhayl.

In this story we find sentences like:

1) "Al-Fudhayl Ibn Iyaad was a notorious criminal at 'his' time",

2) “'he' was a highway robber",

3) “"he' was so feared by the population",

4) "'he' looked up at the second story of a house",

5) As 'he' was climbing the wall, 'he' heard a low voice reciting the book of Allah (Qura'an),

6) “'he' crawled back down”, ...etc.

The long distance of place and time between the speaker and the character of the story is clearly shown by using the third person pronouns which are mainly used for this purpose.

Likewise, the Imam used the pronoun 'it' to refer to the fish in the metaphorical example that he used to show a resemblance between the fish and the believer:

1) "Imagine how the fish would be if 'it' was taken out of water",

2) “'it' starts flapping around, trying to get back into 'its' environment",

3) 'there is a level of worry, anxiety, anger when 'it' is taken out of 'its' natural state".

The second person pronoun 'you', on the other hand, is used to indicate the person or persons being addressed. 
The Imam used this pronoun for 69 times in his speech, so it is the most frequent used pronoun after the third person pronoun. When the speaker addresses his audience directly by using the pronoun 'you', he intends to shorten the distance between him and his listeners. This proximity is so important for the speaker when he wants to deliver an important message, in this context, strengthening our faith in Allah.

To achieve this goal, the Imam used this pronoun, because it has a feature of specification and determination, bind and obligation, and taking responsibility. It is also used for advice and guidance, showing appreciation and endearment to the addressees, as well as making the audience indulged in the context of the speech. This is why we find this pronoun widely used in such texts. Here are some evidences:

1) "... so the question of the fortitude of 'your' imaan (belief) is a most important issue that relates to matters of the heart",

Note that the Imam used 'you' when he talked about (belief) as a most important issue related to the doings of the heart.

2) “... the Qur'an which was sent as a direction for mankind, and requires 'you' to read with an open mind and an open heart. With this, 'you' will increase 'your' knowledge and awareness of the Qur'an."

3) “... it provides proof and evidence which will strengthen 'your' Imaan, and implants in 'your' heart a desire which pushes 'you' to put 'your' trust in Allah, and this trust and attachment 'you' begin to develop comes from the core/foundation of 'your' faith."

4) "The more 'you' learn about everything, the more 'you' will become amazed by Allah."

5) "When 'you' looked at Allah's signs, 'you' begin to understand who He is."

In these examples and others, it's noticeable that the Imam used 'you' profusely when pointing to God's splendid creation. He wanted to bind the listeners directly with the signs of His miraculous creation, so that his intention of increasing the audience's belief will be accomplished.

See also the pronoun 'you' in 'Rely on Allah for the little things-this is a clear indication that 'you' are attached to Him ..." which is used to bind the man directly to his Creator in a relationship full of love and endearment.

In addition, we can see examples of guidance and advice in such utterances as, "When Allah blesses 'you' with ni'ma, part of your gratitude, is to not waste it, or to use it in a wrong way",

“Go on a diet from 'your' phone ... do something for a scheduled amount of time. Schedule 'your' faith-bases activities", where the Imam urging his audience to be grateful to Almighty God for his blessings, and not to waste their precious time in being busy with their phones day and night.

The Imam also used the first-person pronouns ' $\boldsymbol{w e}$ ', ' $\boldsymbol{u s}$ ', and 'our' to show that he put himself as one of the Muslim group and needs the guidance and advice like them, and that both of them have the same ambitions and aims; being closer to Allah by elaborating forms of obedience.

These pronouns usually refer to strength, unity, and common destiny. They indicate that "we're speaking as a group."

In “'We' praise Him and seek his help and forgiveness. 'We' seek refuge in Allah from 'our' souls' evils and 'our' wrong doings", the speaker is indulging himself with the addressees in that they all share the same opinions, feelings and needs. They all praise almighty God and ask his refugee from their soul illness and evil deeds, no one of them is excepted from this.

In the same sense we find: “... it becomes hard for 'us' as Muslims to maintain 'our' identity ..." where the speaker also put himself within the Muslims group who should be responsible for defending their Islamic identity.

In addition, the speaker from time to time was showing his humility by using 'we' and 'our' when talking about shortfalls that are committed by Muslims, as if he is saying "I have my mistakes and pitfalls, because I'm a human being like you". In doing so, he's making the effect of his advice deeper in his addressees' souls and hearts. Here is an example: "As 'we' are nurturing the body with the wholesome balanced diet, we should do the same with the soul, if 'we' do not, then 'we'know 'we' will get sick-in the same way the soul can also get sick. This addresses the issue of imaan being weak."

In "only by Allah's mercy 'you' are being protected. So increase 'your' imaan, by remembering these things, and then by showing 'our' gratitude, and if 'you' show gratitude, 'you' get more", we can observe the shifting from the second person pronoun 'you' and 'your' to the first-person pronoun 'our', a matter which indicates that the 
speaker has double tasks, first as being a preacher, so he was directly addressing his listeners by using 'you', and second as being a member in the Muslim group and sharing the same destiny by using 'our'.

The use of the pronouns 'me' and 'I' is rare in this text, 'me' is used for two times, and 'I' for two times only, and they do not indicate or stand for the speaker, but they're used by Allah indicating Himself in the verses of the Holy Qur'an or in Qudsi Hadith (sacred hadith). See the following:

"He set the sun and moon in their courses, and then He says: so worship Me",

"If all of you from the beginning to the end, humankind and jin, were to stand on one plane and begin to ask 'Me' everything they want, and 'I' give it to them, it would no detract from what 'I' have ..."

The speaker didn't want to show himself as superior to his audience by using 'I' and 'me' each time, because the repetition of this pronoun may sometimes indicate individuality or selfhood, a matter which could have a bad effect on his missionary work.

\subsubsection{Reasons Behind the Use of Place Deixis}

Place deixis have been also used by the Imam in his lecture, though less frequent than the person deixis.

1) During reviewing the story of Al-Fudhayl Ibn Iyad, the Imam used spatial deixis to refer to the place where the event of the story took place. Consider the following:

“... Fudhayl Frose, thought about it, and he crawled 'back' 'down' and sat 'underneath' a tree in the shade from the moonlight", these deictic words show the place where the event took place, a house of a beautiful girl whom he wanted to seduce, and then he heard a verse from the Holy Qur'an recited by someone, so he repented and turned down the house and sat under the tree thinking about what a horrible thing he was about to do.

2) The Imam also used those expressions when he gave an example about the signs we find in nature that refers to the perfection of God's creation, "The sea turtle 'comes' to shore to lay eggs. The turtles 'come' out of eggs, 'go' 'back' to the sea, they have direction ...". The motion verbs 'come' and 'go' clearly show the movement from the sea to the shore and from the shore back to the sea in a miraculous scene.

3) We also find the distal deixis 'those' in the following Quranic verse "Allah doesn't like 'those' who do not do what they say ..." which refers to what is called 'psychological distance' as suggested by Yule (1996, p. 13). In other words, sometimes the speaker may wish to mark something that is physically close as psychologically distant if he doesn't like it for a reason or another (Ibid). in this context, Almighty God uses the word 'those' to refer to distant hateful people who are insincere and have bad manners. A word like 'those' doesn't have a fixed semantic meaning, rather it is invested with meaning in a context by a speaker.

4) Another distal deixis can be seen in the following sentence: "Allah has perfected His creation, everything measured, proportioned ... Everything is 'there' for a reason", in which 'there' is used to refer to the places outside the hall where he was giving his lecture, trying to draw the attention of his audience to God's magnificent creation wherever they go.

\subsubsection{Reasons Behind the Use of Time Deixis}

In this text, one proximal time deixis has been found, and two distal time deixis, as well as four other time deictic expressions.

In the following examples, a distal deictic expression is found: "Al-Fudhayl Ibn Iyad was a notorious criminal 'at his time', he was a highway robber, which was a big deal at 'that time' ...", where 'that' refers to the past time, the long time ago when he lived as a bandit.

In the same context, we see: "It was at 'that moment' he made Tawbah (repentance) 'at the moment' of sin ...", where the Imam also used "that" to focus on the specific time in the past that Al-Fudhayl repented from being a highway robber.

In the previous examples, we also find other temporal deictic expressions: "at his time", and "at the moment" which indicate the same meaning.

Consider also: "In 'these' troubling days, ... it becomes hard for us as Muslims to maintain our identity ...". The Imam used the proximal deixis 'these' to make the audience understand that the days he meant are the present days, the days of our time which are full with troubles, doubts, confusion and adversities. So, he intended to worn his listeners to get ready and strengthen their belief, because it's the most important issue in Islam. 


\section{Conclusion}

The research has come to the following conclusions:

1) Deixis is a term that deals with words or expressions whose interpretation relies on the context of utterance and the speaker intention. Therefore, deixis is an important subject in the field of pragmatics which plays a crucial part in human language.

2) Context of situation is very essential in the interpretation of words and expressions, including all types of deixis, because it provides important information about the environment in which these expressions occur.

3) The researcher has counted many deictic expressions in this text namely, person, place and time deixis, in which the person deixis is recorded to be the most frequent type among other types.

4) The third person pronouns are the most frequent person pronouns appeared in this text (98 times), then the first-person pronouns (35 times) only.

5) Using person deixis more than place and time deixis in religious texts could be due to the following reasons:

a. religious texts are usually centered on the Divine Entity, thus the speaker usually refers to Almighty God by using the third person pronoun 'He', including the reflexive and possessive pronouns 'Him' and 'His', because God is the source of inspiration and religious guidance.

b. in giving advice and guidance, the speaker addressed his audience directly by using the pronoun 'you'. In this way, he would be able to draw their attention to his aim and make his words more effective in their souls.

c. the speaker used the first-person pronouns, 'we' and 'us' from time to time to make his audience feel that he is a member of the Muslim group and shares the same destiny with them.

6) It has been noticed that place and time deixis occur only during narrating stories and setting examples which are somehow few.

\section{References}

Al-Tekreeti, A. S. S. (2016). A Pragmatic Analysis of Deixis in John Austin's 'Pride and Prejudice'. Unpublished M.A. Thesis, Suleyman Demirel University.

Awwad, M. (2017). Exophoric and Endophoric Awareness. Retrieved August 12, 2018, from https://works.bepress.com

Banjar, S. (1985). A Dictionary of Linguistics. Linguistics and Phonetics. London: Page Bross Ltd.

Brandford, W., Maurice, V. A., Dace, R., Keating, P., \& Pinchuick, J. (1980). Structure Style and Communication. Oxford: Oxford University Press.

Casson, R. W. (1981). Language Culture and Cognition: Anthropaogical Perspectives. New York: Macmillan Publishing Co. Inc.

Chastain, C. H. (1975). Reference and Context. In G. Keith (Ed.), Language, Mind and Knowledge (pp. 194269). Minneapolis: University of Minnesota Press.

Crystal, D. (1985). A Dictionary of Linguistics and Phonetics. London: Page Bross Ltd.

Dandeigo, R. (2018). Social Deixis. Retrieved August 8, 2018, from https://geogl/images/KBtwso

Edwards, A. D. (1976). Language in Culture and Class: The Sociology of Language and Education. London: Heinemann Educational.

Ello. (2018). Discourse Deixis. Retrieved August 7, 2018, from http://www.ello.uos.de>EarlyModernEnglish

Getty, J. P., \& Tolkien, J. R. R. (2018). J. R. Firth-New World Encyclopedia. Retrieved August 3, 2018, from http://www.newworldencyclopedia.org $>$ entry

Glossary Terms. (2018). What is a Personal Deixis SIL Glossary of Linguistic Terms. Retrieved August 5, 2018, from https://glossary.sil.org $>$ terms $>$ persondeixis

Glossary Terms. (2018). Absolute Social Deixis. Retrieved August 8, 2018, from https://glossary.sil.org>term>persondeixis

Huang, Y. (2007). Pragmatics. Oxford: Oxford University Press.

La, L. (2014). Expophora and Endophora. Retrieved August 12, 2018, from https://mw.losban.org>papri> 
Maryam, K. (2014). How to Boost Your Imaan. Lecture by Br. Imam John Starling at Queens College. Retrieved August 27, 2018, from https://kashmirmariyam.wordpress.com

Mey, J. L. (1996). Pragmatics. An Introduction. Cambridge, Massachusetts, USA: Blackwell Publishers Inc.

Palmer, F. R. (1976). Semantics. Cambridge: Cambridge University Press.

Paltridge, B. (2003). Discourse Analysis. Botmin, Cornwall: Mp6 Books Ltd.

Song, L. (2010). The Role of Context in Discourse Analysis. Retrieved August 1, 2018, from https://www.semantic:choler.org

Sperber, D., \& Wilson, D. (1982). Mutual Knowledge and Relevance in Theories of Comprehension. In N. V. Smith (Ed.), Mutual Knowledge (pp. 61-85.). New York: Academic Press Inc.

Stern, G. (1968). Meaning and Change of Meaning. Bloomington: Indiana University Press.

Wijaya, A. (2012). Place Deixis. Retrieved August 5, 2018, from http:// awinlanguage.blogspot.com

Wijaya, A. (2012). Social Deixis. Retrieved August 5, 2018, from http:// awinlanguage.blogspot.com

Yule, G. (1996). Pragmatics. Oxford: Oxford University Press.

Yule, G. (2010). The Study of Language. Cambridge: Cambridge University Press. https://doi.org/10.1017/CBO9780511757754

\section{Appendix A}

\section{The Religious Text}

https://kashmirmaryam.wordpress.com/2014/10/23/how-to-boost-your-imaan-lecture-by-br-imam-john-starlingat-queens-college-10222014/

\section{How to Boost your Imaan: Lecture by Br. Imam John Starling at Queens College, 10/22/2014}

October 23, 2014/Kashmirmaryam

Innalhamda lillahee, nahmaduhu wa nasta'eenuhu wa nastaghfiruhu, wa na'oodhu billaahi min shuroori anfusinaa wa min sayyiaati a'maalinaa. Mainyah dihillaahu falaa mudillilahu, wa mainyudlil falaa haadiya lah.

"Alhumdulillah. Indeed, all praise is due to Allah. We praise Him and seek His Help and forgiveness. We seek refuge in Allah from our souls' evils and our wrong doings. He whom Allah guides, no one can misguide; and he whom He misguides, no one can guide. I testify that there is no true God worthy of worship except Allah, and that Muhammad (pbuh) is the Messenger of Allah."

1)In these troubling days, days filled with doubts, confusion, misconception, which are very cloudy, very hazy, it becomes hard for us as Muslims to maintain our identity, and so the question of the fortitude of your imaan (belief) is a most important issue that relates to matters of the heart.

2) Allah is most interested in matters of the heart. On a day when neither wealth nor sons will save one, except for the one who comes to Allah with a sound heart and pure heart.

3) The heart is the seat of imaan. The heart is a morsel of flesh that if corrupt, the whole body becomes corrupt.

4) Prophet SAW put emphasis on purifying the heart and strengthening the imaan.

5) The nature of imaan, is that it goes up and goes down. Imaan is affected by our actions, and what we feel in our heart, and by what we say.

6) Imaan is a statement of the tongue, but also actions outwardly done on the limbs - it increases with righteousness, and it is decreases with sins and transgressions, so we see how our actions can affect our imaan. even to the point that imaan can also become non-existent in the heart of a 'Muslim', depending on the nature of the sin.

- The theif is not a believer whilst they are in the act of committing theft- it means they are weak in imaan, but not to the point that they have left the faith.

- The book - majmoo al fawaa'id - 'collection of benefits' — by Shaykh Nasr asSa'adi- he is a very well-known scholar of recent times, who passed away in the 1950's. He was considered as one of the students of Ibn Al Qayyim (even though Ibn-Al_Qayyim was from the middle-ages). Sa'di was considered as such, because he dealt with issues of the heart and the soul, just as Ibn Al-Qayyim was famously renowned for; even in his style of writing and reflection. Some of Sa'di's works are being translated into English, one of those is the 'Beneficial Means to 
living a Happy Life' —*you can download this book as a free pdf file online.*

- Imam Sa'di, was one of the first scholars from his region that authored a complete work of tafseer (detailed contextual and literary understanding of the Quranic verses) - it is on its way to being translated. Sa'di says, there is a crucial benefit - which is struggling and striving in what will nourish and nurture your Imaan. As we are nurturing the body with a wholesome balanced diet, we should do the same with the soul. If we do not, then we know we will get sick- in the same way the soul can also get sick. This addresses the issue of imaan being weak. The reality is that it only occurs with His blessings SWT.

\section{Advice 1 for increasing One's iman:}

Sa'adi said from the most powerful way of increasing faith is through reflection of the Quran, not just through the recitation (though the recitation of the Quran is of great benefit). More powerful than the simple recitation of the Quran is reflecting on the Quran - which was sent as a direction for mankind, and requires you to read with an open mind and an open heart. With this, you will increase your knowledge and awareness of the Quran-it provides proof and evidence which will strengthen your Imaan, and implants in your heart a desire which pushes you to put your trust in Allah SWT, and this trust and attachment you begin to develop comes from the core/ foundation of your faith.

With some guidance and instruction on how to interpret the word of Allah, whether it is through Ibn Kathir translation or through a teacher. Reading over that, it leads a person to understanding their faith, and the power of that can be life-altering.

We often hear of people coming to Islam just through the recitation, and the understanding of the verses, and then they submit to Allah, all the way back to the time of the Prophet SAW. Al-Fudhayl Ibn Iyaad, was a notorious criminal at his time; he was a highway robber, which was a big deal at that time especially, as most people that travelled would take most of their wealth with them (for business and trading purposes etc.) He was so feared by the population, that the mothers used to threaten their children into being good, with Fudhayl's name. One evening, it was said, that Al-Fudhayl was walking and he looked up at the second story of a house, and he saw an attractive girl, so he of course living in criminal sin (living according to desire), he begins to climb the wall. As he was climbing the wall, he heard a low voice reciting the book of Allah (Quran). Al-Fudhayl was a muslim, and he heard the verse, "is it not time for the people of faith, for their hearts to feel awe of Allah in His remembrance.". Fudhayl froze, thought about it, and he crawled back down and sat underneath a tree, in the shade from the moonlight. It was at that moment he made Taw-bah (repentance) at the moment of sin, when the Imaan is typically most low; he repented, and he went on to become Imam of al-haramayn (imam of both the masjid in Makkah and Madinah), and became active in da'wah. How powerful was the effect of this verse on the life of Fudhayl!

\section{Advice 2 for increasing One's iman:}

The second point that Sa'di mentions is understanding and awareness of the Prophet SAW- studying the Seerah. This is the second part of the Shahaadah (testification of 'There is no true God except Allah, and Muhammad SAW is the final Messenger of Allah'), so then it is a part of imaan. Listen and become acquainted with his Ahadeeth, his characteristics - both physical and in his actions/mannerisms. Studying this will increase your certainty. If someone comes up to you and challenges the Prophet SAW, then this can be a moment of doubt for you, because you fall into error with regards to your certainty.

\section{Advice 3 for increasing One's iman:}

Thirdly, think about the signs of Allah-The ayaat. There are two types of ayaat-1. Ayaat in the Quran, and 2. Ayat- al kawniyah - the signs we find in creation. Allah has perfected His creation, everything measured, proportioned - it has been created and directed. Everything is there for a reason. Nothing was left on its own to grow. The sea turtle comes to shore to lay eggs. The turtles come out of eggs, go back to the sea, they have direction they are programmed in that way (do not go inland).

There are varieties of signs we can look at, there are many species of plants, thousands, and all have unique purpose and design. Because Allah is The Greatest, most Magnificent.

Allah commands us in the Quran 'Undhuru'- this means 'look', using your sight, but also has the definition of look with regards to 'reflect'. The more you learn about everything, the more you will become amazed by Allah because of His creation. Allah tells us in the Quran, he set the sun and moon in their courses, and then He says 'so worship me'. This is because through the understanding and pondering over creation, you realize you owe Allah thanks, gratitude and servitude, and so you submit and worship Him naturally. By doing so you increase in worship. From the poetry of Sa'di, he says, 'our faith is speech, action. Of righteous good deeds it increases, with sins, it declines'. Faith goes up with good, and goes down with evil. When you look at Allah's signs, you begin to 
understand who He is, All-Powerful and All-Knowing, and this brings you closer to Him.

\section{Advice 4 for increasing One's iman:}

The fourth advice is to look into and study the lives of the Righteous predecessors, the companions, what they gave for their faith and how/what they sacrificed. Everything seems practical to us, but when you look at their lives you see the practicality of their lives, V.IMP Advice*** Doing good deeds, is a sacrifice that you make, i.e. when praying fajr you sacrifice your comfort and your sleep. Good deeds always involve sacrifice. You sacrifice your career, your time, your money, your friends. With sacrifice, you are giving that thing value. If you do not sacrifice something for something, you do not value it. The more value you see in something, the more you will sacrifice for it. The Prophet SAW did not go untouched by harm. Enrichment in faith comes through sacrifice of things.

\section{Advice 5 for increasing One's iman:}

Dhikr: the legislated forms of remembering Allah. Ibn Taymiyyah said:"remembrance of Allah is to the heart as water is to the fish". Imagine how the fish would be if you were taken out of water.... it starts flapping around, trying to get back into its environment. The heart was pre-programmed, so there is a level of worry, anxiety, anger when it is taken out of its natural state. This is why tranquility and contentment cannot be brought, because these things do not satisfy the heart. The fish starts flapping and then chokes, and eventually dries out and gets hard. Just as the heart will do once it's left out too long, it gets hard, and this stage is extremely detrimental.

A person should be in a constant state of remembrance, and they should increase the dua (supplication). The Prophet SAW, said Dua is a form of worship. Regardless of what you are asking for, but the fact you are doing it in itself is a very pure form of worship, and in and of itself is a cause for your faith to increase. It means you are submitting, requesting, and turning to Allah. Through this you become pure, and you are acknowledging Allah as the most-High, this is Ubudiyyah, you begin to ask Allah for the big things, as well as the very little things. Sometimes we reserve our dua for the big things, as if your dua will run out. However, the Prophet SAW in hadith Qudsi, (where Allah says), "If all of you from the beginning to the end, humankind and jinn, were to stand on one plane, and begin to ask Me everything they want, and I give it to them, it would no detract from what I have, except the likeness of the needle dipped into the ocean, and then when it is removed, and what water is taken with it (i.e. negligible)." Rely on Allah SWT for the little things- this is a clear indication that you are attached to Him. From that Dua, is the athkhaar al yawm al-Layl. When you wake up what do you say? What are the duas you make? Or is it that you are reserving them for the big things, i.e., Exam week... This is the medicine of the heart, the remembrance of Allah, there is a reminder to be had, and with this, imaan is increased.

\section{Advice 6 for increasing One's iman:}

Six-Reflect and think about the many blessings Ni' aam of Allah. If you count and enumerate the blessings of Allah, you will not be able to comprehend what they are, nor will you be able to understand the nature of them. Allah has blessed us in so many ways. Think about what He has protected us from. Turn the news on and look at the condition the Muslims live in, the dire conditions. Only by Allah's mercy you are being protected. So Increase your imaan, by remembering these things, and then by showing our gratitude, and if you show gratitude, you get more. So it only builds on itself.

\section{Benefits to be taken from the $Q$ and $A$ session:}

- Whoever leaves something for the sake of Allah, then Allah will replace it with something better: this is a part of Tawakkul.

- Every disease spiritually is rooted in ignorance. The cure for this type of disease is the opposite, which is al-Ilm, knowledge. The Prophet SAW said knowledge is obtained by learning, and actively engaging in it.

- When Allah blesses you with ni'ma, part of your gratitude, is to not waste it, or to use it in a wrong way. Milk out any beneficial moment from our lives. Fruits reaped from time management is to first identify what first is a time-waster. I.e., Your PHONE! Go on a diet from your phone. Do something for a scheduled amount of time. Schedule your faith-based activities.

- The salaf (pious predecessors) said, if you eat less, you go to the bathroom less, thus spending less time overall. Scholars, used to eat bread and water, but to save time they would pour water on the bread so he didn't have to take time to sip water.

- Laziness has to be combatted, laziness propels more laziness. The prophet SAW sought refuge against this.

- Allah does not like those who do not do what they say. Indeed in the Messenger of Allah, SAW, is a good example. 
- To spread Islam, is a communal obligation. Meaning if there are some members are going ahead and doing it, and then they will not be held accountable. As a female, do not fall into a compromising situation, same with male.

- When giving da'wah go into the fundamentals of Islam.

- It is not permissible for the one who has an accent except if the rest of the congregation has the same accent. I.e., if their recitation has not been perfected

\section{Copyrights}

Copyright for this article is retained by the author(s), with first publication rights granted to the journal.

This is an open-access article distributed under the terms and conditions of the Creative Commons Attribution license (http://creativecommons.org/licenses/by/4.0/). 